\title{
Scientific Governance and Colonial Institutions, c. 1800-70
}

In 1806 colonial possession of the Cape, which had shifted uncertainly between the Dutch and British from 1795, was finally resolved and the tip of Africa became a permanent fixture of the British Empire. Under the Batavian Republic and the brief tenure at the Cape of the Dutch statesman J. A. de Mist (1803-4) there were suggestions of reforms in governance which may have given a boost to scientific inquiry and bureaucratic modernisation. But these were scarcely realised amid the disruption of the Napoleonic Wars.

Britain's major motive for claiming the Cape was the control of sea routes and its naval presence there became disproportionately large. The difficulties of conquest on the expanding eastern frontier of the colony necessitated substantial military forces. And, partly for this reason, the new British administrations sought to coax the Cape into an economically productive colony of settlement. Changes in the law, in administration and to currency, were all designed to improve governance. Yet policies were often inconsistent and the language of reform and progress belied authoritarian and illiberal practices.

The British remained beholden in key respects to the established Dutch elite, especially in the countryside. While British officials and military officers took over the key positions of power, the need for political compromise perpetuated some aspects of the 'old corruption' that Barrow and others had condemned. This included slavery, which remained intrinsic to the second British Empire. British rule thus brought opportunities for these established Dutch families. Some were also accommodating to the policy of anglicisation, first promoted by Governor John Cradock (1811-14). The first Chief Justice appointed in 1812 was a local specialist in Roman-Dutch law, Johannes Truter. $\mathrm{He}$ was also the first South African to receive a knighthood. Lord Charles Somerset, longest-serving Cape governor in the nineteenth century (1814-26), approved some modification of slave conditions, but he found a strong coincidence of interests with the landed 
Afrikaner elite, the major slaveholders and wine producers. Between 1809 and 1825, when protection for Cape wines in Britain was ended, the number of vines doubled, and wine production increased by 80 per cent. ${ }^{1}$

\section{Somerset, Barry and Pringle: The Foundation of New Institutions at the Cape in the 1810s and 1820s}

The Cape presented a military and political challenge for this new colonial government, especially Somerset with his visceral fear of revolutionary republicanism or 'Jacobinism'. For their part, some Boers, especially livestock farmers in the eastern part of the Colony, resented government interference in their control over Khoekhoe workers and the extension of the centralised court system. The major indigenous threat to the Colony was presented by the Xhosa chiefdoms on the eastern frontier. Somerset's attempt to stabilise conflict in the eastern zone by completing a string of forts and recognising Ngqika as Xhosa paramount proved unsuccessful. Ngqika's uncle and regent until his accession, Ndlambe, challenged colonial authority in 1818-19, besieging Grahamstown, the major British military centre in the east. He was ruthlessly suppressed, and the colonial government annexed Xhosa land up to the Keiskamma River as the 'Ceded' territory. This included Ngqika's great place, which was confiscated despite his attempt to forge an alliance with the British.

The first couple of decades of British rule were striking not only for the assertion of control but also for the formation of new scientific and medical institutions and associations. In part this resulted from measures by the new state, which adopted a wider sense of reform-minded governmentality than the VOC; they also developed as reactions to what was perceived as autocratic, gubernatorial rule. New associational and scientific networks, mainly British in form but remarkably cosmopolitan, flourished as the pace of economic growth increased and as Cape Town's population grew from about 15,000 in 1800 to 25,000 in 1850 .

Medical practitioners were by far the most numerous group with specialist scientific knowledge at the Cape, and in 1807 the principal

1 T. Keegan, Colonial South Africa and the Origins of the Racial Order (London: Leicester University Press, 1996), 52. 
medical officer of the Army, Alexander Baillie, formed a commission to regulate them. A proclamation established a Supreme Medical Committee that would examine the credentials of, and license, all physicians, apothecaries and retailers of medicine. As some were not professionally qualified, this constituted a major intervention on the part of the state. Harriet Deacon argues that monopolisation of medical practice by licensed practitioners, excluding both unlicensed settler providers and African practitioners, was unusually early. ${ }^{2}$ While rigorous legislative control of medical practice preceded that in Britain, the law was not systematically enforced. There was also tension between physicians and apothecaries - the latter attempting to restrict the supply of drugs to themselves. Some well-established practitioners such as Dr Friedrich Liesching, who came to the Cape as surgeon-general in a company of mercenaries sent to support the Dutch by the Duke of Württemberg, acted as both: he was a physician who also ran one of the largest wholesale and retail apothecaries in Cape Town.

During Somerset's governorship medical institutions were further transformed. One key figure was his close friend James Barry, who has attracted a number of biographies and fictional treatments: he sustained a successful career as a British Army physician for over forty years, rose to the senior position of inspector-general of military hospitals, and, when laid out on his deathbed, was identified as biologically female. A detailed recent treatment by Du Preez and Dronfield seems to establish firmly that Barry was born Margaret Ann Bulkley, probably in 1789 in Cork, Ireland. ${ }^{3}$ A confident young woman with great intellectual potential, Bulkley moved to London with her mother and was promoted by well-connected friends of her artist uncle, James Barry. These included Francisco de Miranda, an exiled leader of the Venezuelan revolution. ${ }^{4}$ With this support, Bulkley was able to prepare for a medical degree at Edinburgh University (1810-13); entry was barred to women, and so she adopted her dead uncle's name, with the

${ }^{2}$ H. Deacon, 'Introduction: the Cape Doctor in the Nineteenth Century' in H. Deacon, H. Phillips and E. van Heyningen (eds.), The Cape Doctor in the Nineteenth Century: A Social History (Leiden: Brill, 2004), 17-43.

${ }^{3}$ M. du Preez and J. Dronfield, Dr James Barry: A Woman abead of Her Time (London: One World, 2016).

4 R. Holmes, Scanty Particulars: The Strange Life and Astonishing Secret of Victorian Adventurer and Pioneering Surgeon James Barry (London: Viking, 2002). 
middle name Miranda. For the rest of his life, Barry sustained a medical career in the armed forces as a man.

After qualification, further work with a London surgeon, and a few short-term posts as a junior military doctor, Barry arrived in the Cape in 1816 with a letter of introduction to Somerset. By chance the governor's daughter was ill and Somerset gave Barry the responsibility of restoring her to health. Barry was by this time outgoing, welldressed, and equipped with the metropolitan manners that attracted Somerset. He also presented himself as a 'romantic, progressive gentleman scientist', which chimed with Somerset's mindset. ${ }^{5}$ The governor had been part of the entourage of the Prince of Wales (later George IV) and the fashionable Brighton set. Barry was 'welcomed into the bosom of the Somerset family', invited to important dinners and social events, and attended the theatre in the governor's party. ${ }^{6}$ The new doctor also attended 'rainbow balls' described by the colonial secretary Christopher Bird as 'composed of each different hue in this many coloured town'. ${ }^{7}$

In 1820, when Somerset visited Britain for an extended period, his temporary replacement, Rufane Donkin, established a new post of colonial medical inspector, effectively taking over from the Medical Committee to head medical services in the Colony. When Somerset returned at the end of 1821, and the post became vacant, he appointed Barry, despite his inexperience. Barry benefited from the famously rigorous training in Edinburgh and his experience in London; between 1765 and 1825, only 20 per cent of Edinburgh medical students graduated with an MD. Scottish medical education provided many of the Empire's physicians and influenced both practice and, later, training in the anglophone colonial world. Up to this point, most licensed physicians at the Cape had trained in Germany or the Netherlands. Barry was disdainful of much of the medical practice that he had seen in the Cape and set about reform with enormous energy: 'sweeping through each of the public institutions of the Cape - hospital, leper colony, prisons, asylums, apothecaries, commerce in medicines - he ferreted out venality, criticised bureaucratic corruption,

${ }^{5}$ Holmes, Scanty Particulars, 65.

${ }^{6}$ Du Preez and Dronfield, Dr James Barry, 123.

${ }^{7}$ Holmes, Scanty Particulars, 68. 
challenged inefficiency, created detailed policies of medical reform and relieved suffering, 8

Leprosy was reported in South Africa in the eighteenth century, and early British officials became aware that it had spread amongst the Khoekhoe population. ${ }^{9}$ In 1813 it was made the second notifiable disease after smallpox. Initially it was left to the attentions of local officials, but by 1817 a more coordinated response seemed necessary and Somerset approved a leper colony in the Hemel en Aarde valley, between Caledon and present-day Hermanus. Together with the Somerset Hospital for the poor and outcasts of society, this became the first public health institution in the Colony and new buildings were completed in 1820. Little medical support was given, however, and when Barry visited in 1822, he was appalled at the prevailing conditions. ${ }^{10}$ The Moravian missionaries at Genadendal were asked to take over and managed the establishment until it was disbanded in $1846 .^{11}$ Barry visited regularly to ensure that adequate standards were maintained. Hemel en Aarde was replaced by Robben Island in Table Bay, which served as a more isolated leper and 'lunatic' asylum but was also sufficiently accessible to Cape Town to facilitate medical care.

In 1824 Barry revealed dire conditions in Cape Town's gaol. He inspected and wrote an extensive report on Somerset Hospital, which was also the government facility for those declared insane. Again, he was highly critical: 'lunatics were kept in filthy cells better calculated for the confinement of brute animals. ... ${ }^{12}$ He took on the Liesching medical family over the licensing of one of the sons, who had not been to Europe to qualify formally as apothecary. Rather than demonstrating flexibility, as others advised, Barry was uncompromising. Somerset's protection was no longer sufficient and in 1825 the post of colonial medical inspector was terminated. One of Barry's last acts as inspector was to begin the replacement of Cape Town's open sewers with iron pipes. He imagined a rigorous public health regime in Cape Town and went some way towards establishing it. There had certainly been initiatives in the British Army to ensure adequate ventilation,

${ }^{8}$ Holmes, Scanty Particulars, 94.

9 E. H. Burrows, A History of Medicine in South Africa (Cape Town: A. A. Balkema, 1958), 103.

10 Burrows, History of Medicine, 105.

11 Du Preez and Dronfield, Dr James Barry, 175.

12 Du Preez and Dronfield, Dr James Barry, 177. 
cleanliness and sanitation in military institutions, but the scale of change that Barry envisaged was at the cutting edge of scientific thinking.

Barry continued to practise as an army doctor with some private work, usually unpaid. When in 1827 the sister of his landlady, Wilhelmina Munnik, experienced acute distress in the early phases of childbirth, Barry was called. He could not get the foetus to pass through the cervix, even with forceps. Caesarean operations were known, but no British case had been reported of mother and child surviving. Barry's biographers suggest that he had focused on obstetrics (or midwifery) in Edinburgh and read about a successful operation in Switzerland. With a midwife and two servants assisting, the patient biting on a leather strap, Barry operated. He clearly knew sufficient anatomy from his training and practice, and he was already experienced in dealing with wounds in military patients (from fights, as much as wars). Mother and child survived, perhaps because of his fastidious concern with hygiene as much as his surgical skills. The procedure is now generally accepted as the first successful Caesarean operation in the anglophone world. Barry refused payment, suggesting instead that the child be named James Barry Munnik in thanks. The family retained this practice and a cousin of a descendant named their son, born in 1866, James Barry Munnik Hertzog. In this unlikely way, the first Afrikaner nationalist prime minister of South Africa (1924-39) carried the name of a radical British doctor from the early nineteenth century.

Among his other scientific interests, Barry also wrote on botany and pharmacology and was convinced that by examining 'the Natural History of the Cape, its Vegetable Kingdom will be discovered to abound in many rare and valuable medicinal productions' ${ }^{13} \mathrm{He}$ experimented with Arctopus echinatus, which was used in African healing, and believed it could help to treat venereal disease, the curse of the garrison. Existing treatments were complicated and not very effective.

While Barry's international reputation has grown with successive biographies and studies, Somerset has long featured in the historiography as an aristocratic, illiberal governor, who ruled by patronage and suppressed the first stirrings of a liberal press. Yet Somerset actively promoted economic progress in the Colony. Theal, a

${ }^{13}$ Du Preez and Dronfield, Dr James Barry, 221. 
conservative historian sympathetic to the settler view, judged that Somerset was 'as desirous as anyone could be for the improvement of the Colony and the prosperity of its inhabitants ... only everything tending to improvement and prosperity must emanate from himself'. ${ }^{14}$ At the instigation of military officers in 1814, Somerset appointed the eccentric botanist and licensed apothecary, Dr Mackrill, to seek out a favourable place in the eastern Cape for the establishment of a government farm. Mackrill chose a site in the Agterbruntjieshoogte, a favourable spot east of Graaff-Reinet, where earlier travellers such as Sparrman had been hosted by Boer frontiersmen. One aim was to experiment with tobacco and so establish a source other than the United States. A further purpose was to develop agriculture in order to provision troops and horses on this troubled frontier; supply lines from Cape Town were very long and Port Elizabeth was not yet established.

Under Robert Hart from 1817, Somerset farm became a significant centre for intensive food and fodder production and also a depot for produce purchased from the local Boers and then distributed to military posts. The farm turned into the village of Somerset East. Hart started his own farm, Glen Avon, nearby. He was one of the first successful merino breeders in the Cape at the very beginning of the wool boom, which finally promised an export commodity to make the Colony solvent. Groote Post, near Darling in the western Cape, played a similar role, specialising in livestock breeding.

From the very start of his governorship, Somerset promoted the idea of a major British migration to South Africa. Many of the 4,000 new British colonists who arrived in 1820 found it difficult to establish themselves and felt that they had inadequate support from the government. One of their number, Thomas Pringle, headed a Scottish party that settled on a tributary of the Fish River, closer to Somerset farm (about $30 \mathrm{~km}$ away) than to the major concentrations around Grahamstown (about $150 \mathrm{~km}$ ). Pringle visited the farm, which greatly impressed him, and met Hart, the head of the project. ${ }^{15}$

Pringle and Barry were born in the same year, 1789, and both overlapped in Edinburgh. In 1817, when Pringle, developing his

14 A. K. Millar, Plantagenet in South Africa: Lord Charles Somerset (Cape Town: Oxford University Press, 1965), 6.

15 T. Pringle, Narrative of a Residence in South Africa, vol. 1, 52. (Brentwood: Empire Book Association, 1986), first published 1834. 
literary ambitions, helped to found the Edinburgh Monthly Magazine, Barry had arrived at the Cape. In 1822 Pringle moved to Cape Town to become librarian at the South African Public Library, newly established with Somerset's approval and drawing on the proceeds of a tax on wine and brandy. Soon after its foundation the library benefited from the addition of 4,500 books - including a first edition of the works of Descartes - assembled by the German VOC official Joachim von Dessin (d. 1761), whom Lacaille considered to be one of the most influential men at the Cape in his day.

Around the time that Pringle became librarian, Barry donated some of his medical textbooks, and advised the library committee about the purchase of further medical books. It is very likely that they met through this connection - and they shared an antipathy to slavery. Pringle was initially impressed by Somerset and later noted in his Narrative of a Residence in South Africa (1834) that the governor had approved capital punishment for a white man for the murder of a slave 'for the first time in the history of the colony'. ${ }^{16}$ But Pringle crossed swords with the government over the plight of the 1820 settlers, for whom he acted in Cape Town. He soon found Somerset and key officials both uninterested and intolerant - leading what Pringle termed 'the Cape "Reign of Terror". ${ }^{17}$

British settlers, not least those in Cape Town, sought to assert themselves as citizens with rights as well as responsibilities. In the eastern Cape, the majority developed strong anti-emancipationist and racist views, fuelled by a sense of vulnerability and resentment at their indifferent treatment by officials. In Cape Town a small group of British colonists articulated specifically liberal, emancipatory ideas. Missionaries like John Read and John Philip took a lead in defending some of the legal rights of the colony's indigenous subjects. Although initially representing the settlers, Pringle was also an advocate of progressive colonial freedoms for black as well as white. Together with his Scottish compatriot John Fairbairn, Pringle started a school in Cape Town and founded the South African Journal. They claimed the right to publish without censorship and the necessity for a 'general diffusion of knowledge, Piety and civilisation throughout this extensive Colony'.

16 Pringle, Narrative of a Residence in South Africa, vol. 1, 148.

17 Pringle, Narrative of a Residence in South Africa, vol. 1, 157. 
The Journal lasted for two issues only. A new venture followed in 1824 when Fairbairn and Pringle, with George Greig, founded the South African Commercial Advertiser. This was soon quashed by Somerset. The governor's fight against a free press was certainly rooted in reactionary sensibilities and fear of political opposition and Jacobinism. However, his immediate motivation was also to suppress the full record of a trial in which Somerset claimed he was libelled; one of those charged was also suspected of displaying a pamphlet suggesting a homosexual relationship between Somerset and Barry.

The Commercial Advertiser sought to root radical principles of the Scottish Enlightenment in African soil. Among the prominent themes were calls for social and economic progress, improvement and reason - ideas and values that also helped to underpin claims to colonial respectability and patriotism. The irony is that Barry was pursuing some of these improving aims in the sphere of medicine and public health and that he was immobilised not by Somerset, but by the Cape functionaries and medical men with whom he had clashed. Somerset remained adamantly opposed to a free press and seems to have been personally outraged by Pringle. Progress, as Theal suggested, had to be controlled by the governor.

The campaign to publish free of official censorship was accompanied by efforts to expand associational life by forming clubs and societies. From the mid-1820s a range of new scientific and literary institutions emerged in order to give voice to embryonic forms of civic assertion. A South African Literary Society was revived, but suppressed soon after its creation in $1824 .{ }^{18}$ Sir John Truter had decided to join the Society, 'as the promoter of science and literature in the colony', but Somerset was so strongly opposed to Pringle and Fairbairn that he 'called the Chief Justice to his presence, and gave him such a rating ... that Sir John, almost frightened out of his wits', withdrew. ${ }^{19}$ Somerset also warned off the lawyers and merchants who had supported the revival.

\section{Zoology, Astronomy and Survey at the Cape: Smith, Herschel and Maclear}

Somerset and Pringle departed to Britain in 1826, and Barry left the Cape soon after. Pringle became secretary to the Anti-Slavery Society

18 Dubow, A Commonwealth of Knowledge, 29-34.

19 Pringle, Narrative of a Residence in South Africa, vol. 1, 163. 
in London. Ordinance 60 of 1829 established the right to publish at the Cape and, following Somerset's departure, the scope for civic organisation expanded rapidly. The South African College was founded in 1829, as was the South African Institution, which launched the country's first scientific publication, the South African Quarterly Journal, in 1830. This publication, which remained in existence until 1837, served as an outlet for nineteen scientific papers by Andrew Smith, a medically trained Scottish explorer, traveller and naturalist.

Smith qualified in medicine at Edinburgh and worked initially in the eastern Cape. He was responsible for the creation of a private museum in Cape Town in 1825 dedicated to 'the reception and classification of the various objects of the Animal, Vegetable and Mineral Kingdoms which are found in South Africa'. The museum benefited from donations and natural history specimens contributed by locally based naturalists, including the botanical collector Baron Carl von Ludwig and the taxidermist Jules Pierre Verreaux. The Paris-based firm Maison Verreaux maintained a branch in Cape Town and was a premier supplier of natural history specimens to museums in Europe and America. ${ }^{20}$ The Verreaux brothers were also responsible for exhibiting the stuffed corpse of a Tswana man in Paris. It ended up on display as 'El Negro' in Banyoles, Spain, and was repatriated to Botswana amid some controversy in 2000.

In 1826 Smith published a Descriptive Catalogue of the South African Museum, which constituted a significant contribution to cataloguing the country's mammalia. His coverage was expanded in the four-volume Illustrations of the Zoology of South Africa (1838) - the fullest record so far. Smith abandoned the form of presentation used by earlier travellers, who weaved their writing about animals into their narrative accounts, and wrote instead a systematic list with illustrations. His sojourn at the Cape lasted from 1821 to 1837 , when he left in order to mount an exhibition in London. This featured natural history specimens from the South African Museum as well as from a major expedition that he undertook to the 'interior of Africa' in 1834-6. His journey brought him into contact with such African

${ }^{20}$ R. Summers, A History of the South African Museum 1825-1975 (Cape Town: A. A. Balkema, 1975), 5-8. 
leaders as Andries Waterboer of the Griqua, Moshoeshoe of the Sotho, and Mzilikazi of the Ndebele. He had earlier also visited the Zulu king Dingane.

Smith was supported in this venture by the newly created South African Literary and Scientific Institution as well as a committee of prominent Cape citizens who issued subscription shares to raise money for his trip. As an explorer and man of science Andrew Smith was a transitional figure, for although he drew on local and official support to sponsor and promote his scientific ventures, he remained an individual traveller in the eighteenth-century sense and his ambitions were ultimately focused on the metropole rather than the Cape. After his return to Britain, he became an army surgeon, rising to the position of director-general of medical services during the Crimean War. ${ }^{21}$

The career of Edinburgh-trained anatomist and naturalist Robert Knox provides a parallel. A decade before his involvement in the infamous Burke and Hare murder scandal, Knox spent three years at the Cape as a military surgeon during which time he likely worked with James Barry. After his return to Edinburgh in 1820, Knox travelled to Paris where he met Cuvier (shortly after Cuvier's dissection of Sara Baartman's body) and Le Vaillant. In 1823 he delivered a talk on anatomical differences between the 'Native Races' of southern Africa. When a group of 'Bushmen' were exhibited in London in 1847, Knox addressed a large audience at Exeter Hall on the relationship between Bushmen and the Khoekhoen - taking issue with Smith's view that they were racially the same. Knox's book The Races of Men (1850), a landmark in racial science, contains a lengthy and characteristically opinionated chapter on 'The Dark Races of Men' in which he expounds on the relative inferiority of indigenous South Africans to the 'white races'. ${ }^{22}$ For Scots as diverse in their political views as Pringle, Smith and Knox, their experience of the Cape in the early decades of British occupation proved formative in their later British careers.

${ }^{21}$ P. R. Kirby, Sir Andrew Smith, M. D., K. C. B.: His Life, Letters and Works (Cape Town: A. A. Balkema, 1965).

22 P. R. Kirby, 'Robert Knox and his South African Research', South African Medical Journal, XIV, 13 (1940), 254-60; R. Knox, The Races of Men: A Fragment (Philadelphia: Lea and Blanchard, 1850), chapter 6. 


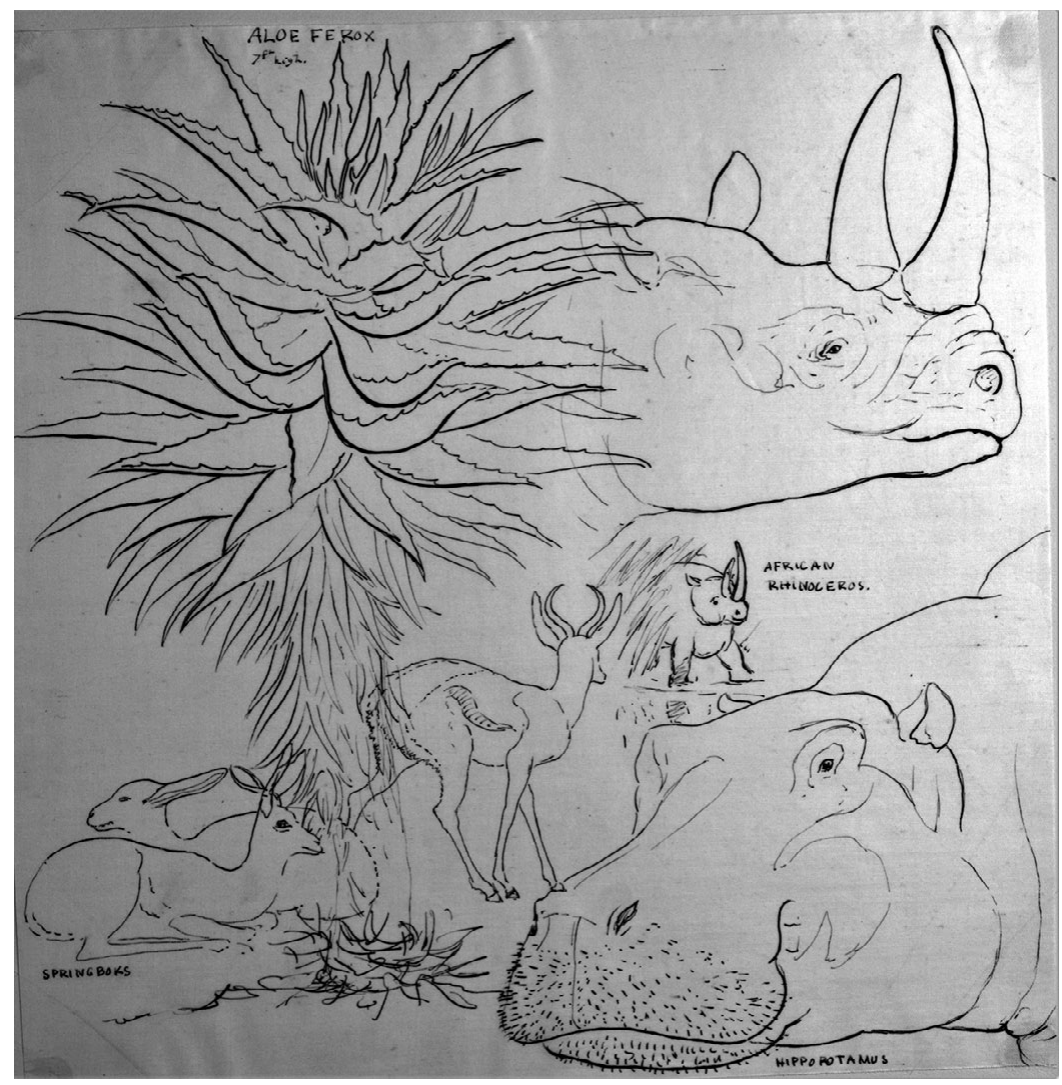

Figure 2.1 Charles Piazzi Smyth, composite sketch of Aloe Ferox, Springboks, African Rhinoceros, and Hippopotamus, from his sketchbook, 'South African Microcosm 1835-1846'.

Credit: Charles Piazzi Smyth Collection, Royal Observatory Edinburgh/Royal Society of Edinburgh, with thanks to Andy Lawrence and Denis Pellerin.

Smith's short-lived private museum catered to a self-selected elite, but it housed the largest variety of animal specimens yet assembled in South Africa for study and comparison. It provided a model for collection and display, and in 1829-30 many of the specimens were transferred to the newly established South African Institution with Verreaux acting as curator. This brought together private collections belonging to Smith, Verreaux, and Ludwig, but it was broken up in 1837 after Smith's departure. The remaining zoological holdings were transferred on loan to the newly created South African College, 
forerunner of the University of Cape Town. ${ }^{23}$ Institutional memories proved short, however, for the establishment of the Albany Museum and the South African Museum in 1855 was mistakenly assumed by many subsequent historians to be the start of museology in South Africa. ${ }^{24}$

The most important early specialist scientific institution, not least judged by its permanence and prominence, was the Royal Observatory, approved in 1820 and completed in 1827-8 under the supervision of the Simonstown naval dockyard. It was intended to be the equivalent in the southern hemisphere of the Observatory at Greenwich. John Barrow, now firmly ensconced at the Admiralty, was one of the principal figures responsible for the decision to locate it at the Cape, together with Joseph Banks of the Royal Society. Banks opined that 'nothing could more essentially promote the glory' of Britain than to take a lead in such an undertaking. King George IV gave it the imprimatur of royal authority as well as financial support. ${ }^{25}$

The Royal Observatory was a handsome building designed by the Scottish civil engineer John Rennie, according to the principles of the Greek Revival, and at considerable cost. Its classical lines and symmetrical mathematical proportioning symbolised both its scientific importance and its significance as an outpost of British astronomy and imperial power (the cover of this book is a somewhat imaginary representation of the building with Table Mountain as a backdrop). The establishment of the Cape Observatory affirmed the Colony's new importance in the post-Napoleonic 'second British empire'. Christopher Bayly's description of this moment as the 'imperial meridian' acquires new meaning given that one of the Observatory's premier scientific programmes was to determine an arc of the meridian, essential for accurate mapping and geodetic surveying as well as for determining the curvature of the earth. ${ }^{26}$

Her Majesty's Astronomers at the Cape, Fearon Fallows (1820-31), Thomas James Henderson (1832-3) and Thomas Maclear (1833-70),

23 Summers, South African Museum, 14-15, 18.

24 Summers, South African Museum, 5.

25 D. Gill, A History and Description of the Royal Observatory, Cape of Good Hope (London: HMSO, 1913), vi; S. Ruskin, John Herschel's Cape Voyage: Private Science, Public Imagination and the Ambitions of Empire (Aldershot: Routledge, 2004), 45-6.

26 Bayly, Imperial Meridian. 
made distinctive scientific contributions. Henderson measured the distance of the Alpha Centauri stars closest to the sun, but he lost patience with the Cape (reportedly deriding the environs of the Observatory as a 'Dismal Swamp among Slaves and Savages') and resigned his post. He subsequently became Scotland's first Astronomer Royal. ${ }^{27}$ Interest in the potential of southern hemisphere astronomical observation had attracted eighteenth-century astronomers Kolb and Lacaille (Chapter 1). The creation of a permanent Observatory made systematic, ongoing research a viable project. Many activities were practical and applied: cataloguing southern hemisphere star positions as an aid to navigation, observing tidal movements, conducting meteorology, and maintaining reliable weights and measures. These allied 'observatory sciences' and routines were intimately associated with a repertoire of precise measurement that reinforced the symbolic and practical authority of British governance at the Cape. ${ }^{28}$

One activity where theoretical and practical objectives could be combined was geodesy (measuring the shape and dimensions of the earth) and land surveying. Both involved the laborious technical task of laying out baselines as a standard of length and triangulating further. This initiative was undertaken at the Cape by Maclear and his assistants Charles Piazzi Smyth and William Mann. Maclear's triangulation project began in 1836 with the establishment of an accurate baseline on the Grand Parade, Cape Town, a key point of public assembly. Thereafter, beacons were placed on mountaintops all the way into the interior. The project involved extensive travel over difficult terrain by ox-wagon. Cumbersome precision instruments (sectors, heliostats and theodolites) had to be carried up and down mountains. ${ }^{29}$ Maclear's endeavour, carried out over some twenty years, resulted in accurate trigonometrical land surveys from Cape Agulhas to the Orange River, and also allowed him to verify and extend the arc of the meridian. His work resolved Lacaille's earlier

B. Warner, Astronomers at the Royal Observatory, Cape of Good Hope (Cape Town: A. A. Balkema, 1979), 34.

28 S. Schaffer, 'Keeping the Books at Paramatta Observatory', in D. Aubin et al. (eds.), The Heavens on Earth: Observatories and Astronomy in NineteenthCentury Science and Culture (North Carolina: Duke University Press, 2010).

29 Warner, Astronomers at the Royal Observatory, 51-2, 56-7; P. Moore and P. Collins, The Astronomy of Southern Africa (London: Robert Hale, 1977), 57-9. 
error and demonstrated that the earth was indeed ellipsoid, as the laws of Newtonian physics suggested. ${ }^{30}$ Maclear was awarded a knighthood for these efforts.

There were close but informal connections between the Royal Observatory under Thomas Maclear and the private observatory established in 1834 by Sir John Herschel at Feldhausen, a Cape Dutch country homestead in the present-day suburb of Claremont. Herschel was already established as a leading British scientist. Educated at Cambridge, he published an overview of scientific disciplines and the theory and methods of science in $1830 .{ }^{31} \mathrm{He}$ made a major contribution to an undulatory theory of light waves and advanced innovative conceptions in astronomy about the scale of the universe and the relationships within it. Following on from Newton, as well as his father William Herschel and others at the cutting edge of the discipline, he conceptualised an almost infinite universe with different types of stars and nebulae. 'Within this beautiful structured encapsulation', a historian has argued, 'is great complexity of detail, and mystery as to the physical nature of many things - nebular matter, comets, our sun itself.' Herschel published his Treatise on Astronomy in 1833, 'stretching ... the English imagination'. ${ }^{32}$

Herschel and his family arrived at the Cape with the express purpose of cataloguing the clusters, nebulae and double stars of the southern hemisphere. To this purpose he installed a 20 -foot reflector telescope in the garden of Feldhausen. In the course of regular nightly 'sweeps' of the southern skies, Herschel identified over 1,700 nebulae as well as 2,100 double stars, which had important implications for his development of theoretical understandings of the Milky Way. Together with Maclear, to whom he was personally close, he observed and recorded Halley's Comet in $1835 .^{33}$

Herschel also became absorbed by the Cape's unique botanical riches, planting his garden with indigenous fynbos bulbs and drawing

${ }^{30}$ B. Warner, Royal Observatory, Cape of Good Hope, 1820-31: The Founding of a Colonial Observatory (Dordrecht: Springer, 1995); B. Warner, Charles Piazzi Smyth. Astronomer-Artist. His Cape Years 1835-1845 (Cape Town: A. A. Balkema, 1983), chapter 4; D. S. Evans, Lacaille: Astronomer, Traveller (Tucson: Pachart, 1992).

31 W. F. Cannon, 'John Herschel and the Idea of Science', Journal of the History of Science, 22, 2 (1961), 215-39.

32 Cannon, 'John Herschel', 238.

33 Dictionary of National Biography, 'John William Herschel'. 
landscapes and mountain views with the aid of a camera lucida. ${ }^{34}$ The expansion of understanding of the range of species in botany, zoology and entomology was coterminous with new conceptions of scale in astronomy. Related scientific interests pursued by this polymath included experiments in chemistry, physics and photography. Herschel served on the committee responsible for Andrew Smith's 1834-6 scientific expedition into the interior and he received birds and fossils which Smith had collected. In recognition of Herschel's scientific standing, he was elected in 1834 as president of the newly constituted South African Literary and Scientific Institution, which now stood at the centre of the Cape's emerging institutional and intellectual life. ${ }^{35}$

Working closely with his wife Margaret, an accomplished illustrator of plants, Herschel participated in scientific and cultural activities. They maintained a wide social circle, yet kept their distance from the conservative elite at Government House. In part, this was because Herschel believed that scientists should eschew patronage - and with his own private means he was able to work independently. There was also a political dimension to this choice, since the liberal-minded Herschels disapproved of the harsh realities of colonial rule, in particular the bitter wars on the expanding eastern Cape frontier and settler resistance to slave emancipation. Margaret Herschel recorded in her diary that they were 'delighted' by the Cape - while noting their disapproval of the 'tyrannical Spirit which Colonies are apt to engender among the Inhabitants towards the Natives'. She identified her husband as being on the 'side which humanity \& justice dictate, \& which is guarded by the mournful minority at the Cape'. ${ }^{36}$

Among the regular visitors to Feldhausen were the missionary campaigner for aboriginal freedoms, John Philip, and the liberal journalist John Fairbairn. Griqua leaders Adam Kok and Andries Waterboer visited Feldhausen and were shown around the Royal Observatory in 1834. When a further war with the Xhosa broke out that year, the Herschels and Maclear showed their disapproval of colonial aggression by absenting themselves from a public dinner in honour of Governor Benjamin D'Urban and his military campaign. ${ }^{37}$

\footnotetext{
34 B. Warner, Cape Landscapes. Sir John Herschel's Sketches 1834-38 (Cape Town: Juta, 2006); B. Warner, Astronomers at the Royal Observatory.

35 Ruskin, John Herschel's Cape Voyage, 32.

${ }^{36}$ Ruskin, John Herschel's Cape Voyage, 56, 54-5.

37 Warner, Cape Landscapes, 132.
} 
On his return to England, Herschel was treated as a scientific celebrity. At a dinner attended by leading scientists to honour Herschel's achievements at the Cape, the marquess of Lansdowne, a leading Whig politician and supporter of causes such as abolition and popular education, portrayed Herschel's expansion of the 'empire of knowledge' as a positive outcome of the post-Napoleonic British acquisition of the Cape and, further, as a benefit to all countries. ${ }^{38}$ For all that Herschel opposed militarist imperialism and aggressive colonial expansion, he supported the principle of the progress and extension of British 'civilisation'. He viewed astronomy as playing a role in the enlightened science of imperial governance and efficient factgathering. ${ }^{39}$ Albeit sympathetic to the plight of the Xhosa, Herschel considered that Africans would have to adapt to colonial rule and their social systems needed to change accordingly. In this regard, he was reform-minded rather than radical. Herschel's social instincts were evident, too, in the field of education where he helped locally based activists like Fairbairn in persuading Governor Napier to institute, from 1839, an advanced form of state-funded education that was independent of church oversight and geared to the acquisition of secular and scientific knowledge.

A notable visitor to Feldhausen was the young Charles Darwin, who docked at Simonstown for nearly three weeks in 1836, on the Beagle's way back from Mauritius. Darwin, who had read Herschel's Preliminary Discourse on the Study of Natural Philosophy, hastened to meet him as well as Andrew Smith, Thomas Maclear, and the colonial secretary John Bell. A dinner at Feldhausen on 15 June was one of the highlights of Darwin's visit.

Yet from a scientific point of view, Darwin found the Cape generally disappointing and, despite travelling through some of the most beautiful parts of the western Cape, with its biologically rich and diverse fynbos and soaring fold mountains, he found the Cape aesthetically unappealing. Darwin scholars have rather little to say about his sojourn there, other than his inspection of a granite-schist contact on a Sea Point beach, shown to him by Smith, which had important implications for the

38 Ruskin, John Herschel's Cape Voyage, 64-5; E. Green Musselman, 'Swords into Ploughshares: John Herschel's Progressive View of Astronomical and Imperial Governance', British Journal for the History of Science, 31 (1998), 420-1.

39 W. Ashworth, 'John Herschel, George Airy, and the Roaming Eye of the State', History of Science, 36, 2 (1998), 160, 171-2. 
understanding of geological upheavals. ${ }^{40}$ Darwin's lack of enthusiasm for the country may have had to do with the fact that he was on the last leg of his journey and keen to return home. The Cape was not an exotic location like the Galapagos or tropical Mauritius, nor was it cultivated and ordered like the English countryside. The very fact that it was by now relatively well studied scientifically may also have diminished its allure: 'the Cape was simply too ordinary'. ${ }^{41}$ Yet that ordinariness or familiarity also made him comfortable in the community of intellectuals with whom he engaged. The Cape, he remarked, was one of those colonies around the world in which "little embryo Englands are hatching, ${ }^{42}$ Darwin began the Origin of Species by referring to John Herschel as 'one of our greatest philosophers'.

\section{Knowledge and Power in the Zulu Kingdom}

Almost coterminous with Lord Charles Somerset's governorship at the Cape was the rise of the Zulu kingdom under Shaka (c. 1816-28). There were direct links between the two centres in that Cape-based traders, who first arrived at Port Natal in 1824, established regular contact with the Zulu. Traders and emissaries such as Henry Francis Fynn and Nathaniel Isaacs, who met Shaka, and Andrew Smith, who visited his successor Dingane, sent back information to the Cape. Additional reports were also gleaned from other intermediaries and from African refugees in the eastern Cape and the interior. In turn Shaka and Dingane were keen to understand and make contact with British colonial power in the Cape; they were also warned of the dangers of colonial encroachment.

Recent analyses tend to dismiss Zulu-centric approaches to early nineteenth-century developments in African societies in the region, and thus minimise the specificity, scale and innovative features of the Zulu state. ${ }^{43}$ Norman Etherington has argued forcefully that little about the Zulu state was new: its regiments, weapons, and methods

40 S. Master, 'Darwin as a Geologist in Africa: Dispelling the Myths and Unravelling a Confused Knot', SAJS, 108, 9-10 (2012), 1-5.

41 W. S. Barnard, 'Darwin at the Cape', SAJS, 100 (May/June 2004), 245.

42 A. Desmond and J. Moore, Darwin (London: Penguin, 1991), 184; S. Sivasundaram, Waves Across the South. A New History of Revolution and Empire (London: Collins, 2020), 306-7.

43 N. Etherington, The Great Treks: The Transformation of Southern Africa, 1815-1854 (London: Pearson Education, 2001); J. Wright, 'Turbulent Times: Political Transformations in the North and East, 1760s-1830s', in C. Hamilton, 
of warfare had all been employed for some decades before. ${ }^{44} \mathrm{He}$ is also sceptical about exaggerated estimates of the size of the army and the frequent comparison made between Shaka and Napoleon. ${ }^{45}$ Yet it is important to recognise that Shaka and Dingane developed an African state that probably had twice the population of, and a larger military than, others in South Africa at the time. They were for a period (and in a similar period to Napoleon) formidably successful in battle, laying the foundation for a powerful and distinct African linguistic and cultural identity.

The Zulu kingdom, consisting of perhaps 250,000 people by midcentury, was not on the scale of major West African states such as the Asante, nor did it develop so elaborate a bureaucratic structure. But state formation was difficult in many African contexts. Relatively limited changes in resources, trade, military organisation and weaponry could confer significant advantages. Innovations by Shaka and Dingane made a difference - including new, militarised forms of royal residence. Excavations at Mgungundlovu, built in 1829 for Dingane, which survived until 1838, reveal an estimated 1,700 houses for a population of about 7,000 people. ${ }^{46}$

Other innovations related to the scale of the amabutho (or regiments) and military technology. At that time, African armies in the subcontinent generally went into war with metal-tipped assegais which they threw, and usually also shorter stabbing spears with a broader blade. Most historians accept that Zulu military technique focused on the stabbing spear; they may even have dispensed with the throwing spear. Improved shields warded off assegais. They were mass-produced centrally from oxhide in larger, oval, standard sizes of about 54 × 30 inches $(137 \times 76 \mathrm{~cm})$, sometimes with uniform colours for the regiments. ${ }^{47}$ The wooden pole on which the oxhide was fixed was

B. K. Mbenga and R. Ross (eds.), The Cambridge History of South Africa: From Early Times to 1885 (Cambridge: Cambridge University Press, 2010), 211-52.

${ }^{44}$ N. Etherington, 'Were There Large States in the Coastal Regions of Southeast Africa before the Rise of the Zulu Kingdom?', History in Africa, 31 (2004),157-83.

45 Etherington, 'Were there Large States?', 181.

46 P. Mitchell, The Archaeology of Southern Africa (Cambridge: Cambridge University Press, 2002), 372.

47 I. Knight, The Anatomy of the Zulu Army from Shaka to Cetshwayo 1818-1879 (Barnsley: Frontline Books, 2015), 101-2. 
sharpened at the bottom to provide an extra weapon. Zulu prowess in close-quarter fighting, using shields and stabbing spears, was honed by experience. Going into battle, the regiments - 'understanding the psychological advantages of display' - beat their shields rhythmically.

Even if Zulu armies were no more than 15,000 strong, this must have created enormous pressure for the production of strong and largebladed iron spears. Archaeologist Tim Maggs finds evidence of an intensification of metal production at the time, an issue that has attracted little attention in historical analysis. Metal- and especially iron-working were deeply embedded skills in African societies of southern Africa. There were important sites of metallurgical experimentation within the area that became the Zulu Kingdom; by 1992, when Maggs wrote on this topic, archaeologists had recorded over 120 Late Iron Age furnaces. ${ }^{48}$

Although the timing is uncertain, Maggs argues that iron was increasingly mined, smelted and exchanged by specialist smiths in the Late Iron Age and that the Zulu kings attempted to expand their control over its production. Oral traditions suggest that 'the rapidly growing Zulu kingdom, in the third decade of the nineteenth century, saw a surge in demand for metalwork to be distributed through the king's patronage'. ${ }^{49}$ Production seems to have been most fully developed around Nkandla, where contingents of the Zulu army assisted specialists with the heavy work of mining and transporting iron-bearing material to the furnaces. Shaka and Dingane controlled the output of spears and distributed them at the royal residences to the amabutho.

Maggs excavated a site at Mabhija in the upper Tugela Basin where there were a number of smelting furnaces, some organised with three adjacent pits. ${ }^{50}$ These seem to have been worked by people identifying as Dlamini, whose chiefdom was conquered by the Zulu (and some of whom fled to become part of the Mfengu in the eastern Cape). The

48 T. Maggs, “"My Father's Hammer Never Ceased Its Song Day and Night”: The Zulu Ferrous Metalworking Industry', Natal Museum Journal of Humanities, 4 (1992), 65-87.

49 Maggs, 'My Father's Hammer', 84.

50 T. Maggs, 'Mabhija: Pre-colonial Industrial Development in the Tugela Basin', Annals of the Natal Museum, 25, 1 (1982), 123-41; G. Whitelaw, 'Precolonial Iron Production around Durban and in Southern Natal', Natal Museum Journal of Humanities, 3 (1991), 29-39. 
traveller Adolphe Delagorgue recorded furnaces of a similar scale at the Mkhuze River, in territory formerly controlled by the Ndwandwe, whom the Zulu conquered in the 1820s. He was told in 1846 that at the time of conquest, 'Djaka [Shaka] had a continual need for quantities of iron for his frequent wars and by these means he was assured of an ample supply, forged by his own subjects. ${ }^{51}$

It seems, then, that Zulu-controlled iron production was expanded by incorporating existing sites in conquered territory, and by intensifying production both at these mines and furnaces and in the heart of the kingdom at Nkandla. The furnaces at the Mkhuze were still operating in 1846, with four relays of six men constantly employed in manning the bellows from about eight in the morning to midnight. 'Their skill in working the iron is worthy of note', Delagorgue recorded; 'their methods, however imperfect and crude they may seem, nevertheless enable them to produce some fine pieces ... their weapons are elegant'. He was highly impressed as he watched the iron-workers sharpening blades. ${ }^{52}$ Maggs calls this intensification a form of 'precolonial industrial development'. It has been suggested that the process used by Zulu smiths allowed some charcoal to mix with the molten ore, thus hardening the iron blades. ${ }^{53}$ Indigenous knowledge was a dynamic field at the time and Shaka, as much as Somerset, appreciated the significance of controlling innovation in the exercise of authoritarian power.

Shaka was also aware of the value of firearms. In 1826, the Port Natal traders, who visited him regularly, joined his forces, armed with muskets, in a major sortie against the Ndwandwe. Under Zwide, the Ndwandwe had been his most formidable rivals but they had retreated north of the Phongola River. Shaka's armies marched north and routed those of Sikunyana, Zwide's son, in close combat. ${ }^{54}$ It is not clear how significant firearms were in the battle, which involved as many as 40,000 Ndwandwe, a large number of whom were reportedly killed. ${ }^{55}$ Dingane seems to have developed strategies both to use firearms (with small specialist contingents) and to counter them. ${ }^{56}$ These, however,

\footnotetext{
51 Maggs, 'My Father’s Hammer', 69. $\quad{ }_{52}$ Maggs, 'My Father’s Hammer', 69.

53 Knight, The Anatomy of the Zulu Army, 110.

54 J. Stuart and D. McK. Malcolm, The Diary of Henry Francis Fynn (Pietermaritzburg: Shuter and Shooter, 1969), 126-7.

55 Etherington, The Great Treks, 151.

56 Knight, The Anatomy of the Zulu Army.
} 
failed at the Battle of Blood River with the Voortrekkers in 1838. It seems possible that Etherington may have underestimated the significance of new military organisation and strategies, coupled with more intensive iron-working - emphasising instead the contribution made by the traders to Shaka's reputation: 'accounts which made his name far more familiar to the world at large than any other king of the heartland, ${ }^{57}$

Karen Flint takes a different approach. She is less concerned with cutting the Zulu down to size or puncturing the mythologies of 'terrific majesty, ${ }^{58}$ Rather, she accepts Zulu distinctiveness and explores some of the innovative aspects of African and hybrid knowledge that contributed to state-making. She suggests that 'African healers played an important role in upholding the authority and national identity of a new Zulu nation. Healers and therapeutics served not only the physical and social body, but the body politic. As the Zulu Kingdom emerged and consolidated its power, medicine helped defeat Zulu enemies, strengthen the king, and create a new sense of national pride and obligation. ${ }^{59}$ Flint uses the term 'nation', as much as 'kingdom', 'chiefdom', 'state', or 'polity', with the implication that these ideas made a significant impact in welding a new sense of identity and unity. She argues for the centrality of medical and ritual practices, as much as the amabutho, in supporting 'a diverse but centralized state' and in securing allegiance to the king rather than a local lineage or chief. Her analysis echoes discussions of the abolition of male circumcision in the Zulu Kingdom at the time.

The oral traditions put particular emphasis on this aspect of Zulu state-building and provide 'insight into the imagination of the Zulu nation state'. ${ }^{60}$ Poisoning and supernatural manipulation were seen as part of bids for power and revenge. Chiefs themselves could derive power from ritual medicine (muthi) and could use them against others. Traditions emphasise the national scale of ceremonies such as rainmaking, with recruitment of key ritual specialists from outside the kingdom. Similarly, Shaka developed the annual first fruits festival into a national event. At such festivals, the king, as healer of the land, accompanied by his doctors and regiments, performed rituals aimed

57 Etherington, The Great Treks, 151

58 C. Hamilton, Terrific Majesty: The Powers of Shaka Zulu and the Limits of Historical Invention (Cambridge MA: Harvard University Press, 1998).

59 Flint, Healing Traditions. ${ }^{60}$ Flint, Healing Traditions, 71. 
at ensuring 'the well-being of the nation and all who lived in it'. Soldiers going into battle were doctored at the king's homestead and those returning were cleansed. In addition to the shield, the Zulu headband, or inkatha, became a pivotal symbol protecting the nation and fostering national unity.

Anthropologists writing in the 1930s, such as Monica Hunter (later Wilson), saw medical and magical or supernatural ideas as entwined with and inseparable from African notions of healing. ${ }^{61}$ Zulu medical thinking at a later stage also included an environmental understanding of disease, and there is evidence of it in the nineteenth century. ${ }^{62}$ The layout of settlements on higher ground, as well as building styles, given the available technology, reflected local knowledge of environmental hazards. Low-lying malarial areas were avoided. Grass was regularly burned around homesteads to keep snakes and insects at bay. Europeans visitors remarked that dwellings were 'kept scrupulously clean', swept daily inside and out; 'neither dirt nor ash were to be seen'. ${ }^{63}$ Tsetse fly zones were avoided. White settlers observed in the 1870s that Africans knew that sleeping sickness in both cattle and humans was transmitted via tsetse flies and sought to minimise contact. David Bruce found the same in the late nineteenth century (see Chapter 3).

Shaka was also interested in the healing skills of the traders and allowed Fynn to treat him for a stab wound. As it was the only material he had on hand, Fynn washed the wound with camomile tea and bound it with linen. After Shaka's doctor administered an emetic central to African concepts of medicine - and administered healing roots, Fynn obtained further medicines and dressed the wound again. ${ }^{64}$ Fynn also learnt African healing strategies and administered them to other traders and settlers. Medicine, Flint argues, was an important means of interchange and, as in the Cape in the eighteenth and nineteenth century, elements of hybrid medical practice were established early in encounters between the Zulu and people from Britain and the Cape.

${ }^{61}$ M. Hunter, Reaction to Conquest (Oxford: Oxford University Press, 1964), first published in 1936.

62 H. Ngubane, Body and Mind in Zulu Medicine (London: Academic Press, 1977).

63 Flint, Healing Traditions, 73.

64 Stuart and Malcolm, The Diary of Henry Francis Fynn, 85. 
Zulu chiefs were also concerned to oversee an element of social order that could be described as public health. They were keen to hear about sick people: 'the king would then most likely give the order to consult diviners so as to discover the nature and cause of his illness. A sick man in Zululand was always an object of great importance. ${ }^{65}$ Although the causes of disease were not generally attributed to infection, elements of the idea were latent; by the mid-nineteenth century, possibly because of white settler influence, there were reports of sick people being isolated. Mpande, the Zulu king from 1840 to 1872, attempted to ban cattle from Natal during the outbreak of lungsickness in the 1850s; and there are similar reports from Mpondoland and the eastern Cape. The notion of infection was probably very restricted at the time, as was also the case in Western conceptions. Nor were all Zulu practices conducive to health; Flint cites kraaling livestock, later believed to spread cattle disease by enclosing them nightly. This practice was also general among settler farmers and became the focus of attempts by early vets to improve livestock management from the 1870 s. ${ }^{66}$

In these ways, hybrid ideas about naming and treating diseases began to evolve in southern Africa. Medical missionaries started to train African assistants, and, from the mid-nineteenth century, African knowledge of plant medicine was sometimes recorded in botanical publications (Chapter 7). More generally, social practices in nineteenth-century colonial Natal were to some degree shaped from below by the colonised. ${ }^{67}$ Thus, from an early period in the colonial encounter with independent African chiefdoms, exchanges in ideas and practices, along with the development of hybrid forms of knowledge, began to take place throughout the region - often far away from the centres of British power and settlement at the Cape.

\section{Museums and Scientific Innovation, 1840s to 1860 s}

The development of institutions at the Cape devoted to the propagation of knowledge in the 1820s was important, yet they resembled small clubs that were for the most part reliant on private subscription

65 Flint, Healing Traditions, 83. $\quad{ }^{66}$ Beinart, Rise of Conservation, chapter 4.

${ }^{67}$ K. Atkins, The Moon is Dead! Give Us Our Money! The Cultural Origins of an African Work Ethic, Natal, South Africa, 1843-1900 (London: James

Currey, 1993). 
with additional public subvention. Notably, boundaries between public and private, amateur and professional, and arts and sciences, remained highly permeable. The South African Public Library lay at the centre of these public-private institutions. Herschel called it 'the bright eye of the Cape', regarding it as vital for the wide diffusion of knowledge. ${ }^{68}$

There were many testimonies to the Library's literary and public value. But its precise purpose and function remained unclear and contested. Among the running debates was whether it should be for reference alone or should operate as a circulating library, the extent to which it should cater for working people as well as the middle class, and whether its remit included the stocking of novels and entertaining literature as well as serious instructional material. The leading liberal politician and attorney-general, William Porter, a great supporter of the Library, took pride in its being a socially inclusive colonial institution which could serve as a beacon of enlightenment. (We have found no records of black people making use of the facility). But there were other voices among its subscribers who favoured restricting it to the anglophone male elite. ${ }^{69}$

The South African Museum was established anew in 1855 with strong backing from Governor George Grey and local dignitaries like Charles Aken Fairbridge. Grey has been criticised for his role during and after the Xhosa Cattle-Killing (1856-7) when he used the opportunity to further incorporate the Xhosa chiefdoms into the Cape colonial order and reduce their people to colonial servants. ${ }^{70}$ But an older liberal historiography recognised him as a leading patron of progressive institutions including schools, museums and libraries. It was on Grey's initiative that the German comparative philologist Wilhelm Bleek came to the Cape. Bleek was responsible for cataloguing Grey's personal library and went on to conduct pioneering and systematic research on Bushman languages, oral traditions and myths. ${ }^{71}$

68 Proceedings of the 25th Anniversary Meeting of the Subscribers to the Public Library, Cape Town, Saturday 6th May 1854 (Cape Town, 1854), 20.

69 Dubow, A Commonwealth of Knowledge, 48.

${ }^{70}$ J. B. Peires, The Dead Will Arise: Nongqawuse and the Great Xhosa CattleKilling of 1856-7 (Johannesburg: Ravan Press, 1989).

71 A. Bank, Bushmen in a Victorian World: The Remarkable Story of the BleekLloyd Collection of Bushman Folklore (Cape Town: Double Storey, 2008). 
Grey's official patronage helped to persuade more than 200 public figures to pledge an annual sum of one guinea to help with the museum's establishment. The first two trustees were the colonial secretary Rawson W. Rawson (replaced in 1860 by Fairbridge) and the colonial botanist Ludwig Pappe. The astronomer Thomas Maclear was elected as a further trustee. ${ }^{72}$ Grey was personally responsible for recruiting the first curator of the South African Museum, Edgar Layard, son of a senior official in the East India Company and younger brother of the Assyrian archaeologist Austen Layard. Edgar Layard arrived at the Cape in 1854 to join Grey's civil service and was seconded to the museum on a part-time basis.

The Cape government also offered a grant to support the Albany Museum in Grahamstown, established in 1855 by a committee of doctors led by William Guybon Atherstone (1814-98). Atherstone was a polymath and a local celebrity with broad interests in medicine, geology, botany and astronomy. He arrived with his large family in 1820, was schooled in Uitenhage, and served as an assistant surgeon in the 1835 frontier war. After medical training in Europe, he returned to Grahamstown in 1839. Atherstone is known for administering the first anaesthetic in South Africa, during a leg amputation in 1847. In addition to the museum, he founded the Albany Hospital in 1858 and became its first medical officer. Geology became a major research interest of Atherstone's after he inspected Andrew Geddes Bain's fossil collection. Botany was another passion, and he helped to establish the Grahamstown Botanical Gardens, donating 100 specimens to start a herbarium. He also became involved in exchanging plants with overseas institutions and experimented with local medicinal plants, drawing on the deep knowledge of Xhosa informants to treat his own patients. In 1864, Atherstone was elected a fellow of the Geological Society of London. Three years later he identified a stone found at Hopetown as a diamond, thus sparking South Africa's mineral revolution. ${ }^{73}$

Atherstone's activities as a serial institution-builder included his help in founding the Grahamstown Public Library. In 1881 he was elected as a member of parliament representing Grahamstown. In the 1860s and

Summers, History of the South African Museum, 22-5.

73 W. G. Atherstone, entry by Alan Cohen in Oxford Dictionary of National Biography; Hammel, 'A Relational History of Mary Elizabeth Barber', 69. 
1870s, when political tensions between the eastern and western parts of the Cape Colony were intense, 'Grahamstown men' like Atherstone were proud of their local achievements. The depth of civic pride associated with these public institutions reflected broader rivalries. Thus, the Albany Museum, whose immediate roots lay in the Grahamstown Medico-Chirurgical Society (of which Atherstone was a co-founder), strove to equal or exceed the South African Museum in importance. But the Cape Town-based South African Museum commanded far greater resources and was duly incorporated by legislation, based on the legal precedent applied to the Australian Museum in Sydney, which opened to the public in 1857.

Layard administered the South African Museum with energy and imagination. He had specialist interests in ornithology and shells and in 1867 he published The Birds of South Africa, at the time the most comprehensive distillation of the subject. But he was otherwise a generalist and amateur, reliant on ingenuity, hard work, and personal connections to build up collections. The mouldering remains of Andrew Smith's defunct museum provided a foundation, as did material objects deriving from Joachim von Dessin's collection. Layard's approach was populist, based on the view that the museum should offer something to everyone and so be a repository for all kinds of 'curiosities'. Animals, insects, geological specimens, coins and ethnographic materials were all put on display, as were figures said to be illustrative of the colony's 'four principal tribes' - Xhosa, Sotho, Khoekhoen and Bushmen. ${ }^{74}$ One of the most significant acquisitions was a stuffed quagga foal, obtained around 1860, which remains the only example of this extinct species of zebra on display in Africa. Layard relied heavily on donations from private individuals, whose offerings were recorded in a regular column in the Cape Monthly Magazine, a mark of public commitment and recognition.

This distinctive local publication, established in 1857 on the model of British quarterlies, and edited for many years by the Scottish brothers Roderick and John Noble, published a rich variety of items of literary and scientific interest. The venture did much to stimulate the development of civic institutions and functioned as a key brokerage for the exchange of ideas. In 1860 the peripatetic South African Museum, which had been temporarily housed above a bookseller in St George's

74 Summers, History of the South African Museum, 28. 
Street, was moved to the wing of a new, well-designed, purpose-built building (modelled after the Fitzwilliam Museum in Cambridge) situated in a prime position at the bottom of the Botanical Gardens. The museum shared these quarters with the South African Public Library, and the dual-purpose building was opened with great ceremony by the young visiting British royal, Prince Alfred, in 1860. Four years later, a sculpture of Sir George Grey was erected by public subscription in front of the entrance. ${ }^{75}$

The combined South African Museum and Library building bookended the rectangular grid-space of the old Company Garden, which extended south-east along Government Avenue towards Table Mountain. The Garden, established by the VOC in 1652, was perhaps the oldest colonial institution with a continuous existence in the country. Over the course of Dutch and British rule, public buildings were sited around or within its precincts, cementing its position at the heart of civic life. An ornamental gateway was constructed in 1791 by the Dutch architect Louis Thibault; a zoo with gateways, designed by the German baroque sculptor Anton Anreith, was opened at the mountain end. By the beginning of the twentieth century, buildings around the Garden included the Old Supreme Court (formerly, the Slave Lodge), Parliament, an official government residence (the Tuynhuis), St George's Cathedral, the Great Synagogue, the Supreme Court (now the High Court), and the South African College (now a campus of the University of Cape Town).

The Garden had historically served as a site for cultivating indigenous species and imported plants. In 1848, after a period of neglect, prominent Cape citizens persuaded the government to proclaim part of the Garden as a botanical preserve and a site of scientific interest. Local critics such as 'Hortulanus' charged that the Garden was neither large enough to serve the interests of the country nor ambitious enough in its scope: its purpose should go beyond the receipt and acclimatisation of exotic imports, to include collecting and preserving indigenous botanical species such as the silver tree or witteboom on Table Mountain. These were 'fast disappearing from their native wilds'.

In 1856 a parliamentary committee concluded that the Botanical Garden, while attractive as a 'pleasurable resort', was a failure from a scientific point of view. It was vital to appoint a curator just as the

75 Summers, History of the South African Museum, 35-6. 
museum had done. ${ }^{76}$ In 1858 Ludwig Pappe, a German physician settled at the Cape, was appointed to the position of colonial botanist. He had been an enthusiastic collector of plants since his arrival in 1831 and collated his publications on indigenous plants and remedies in two editions of a book on Florae Capensis Medicae Prodromus (1850, 1857), which detailed the medicinal uses of local plants and drew distinctions between Boer and Khoekhoe usage. ${ }^{77}$ Pappe was closely inserted into local scientific and professional networks and was well known as a public champion of a dedicated botanical garden as well as the preservation of indigenous trees and vegetation. He had strong connections to Kew, the centre of the British Empire's networks of botanical exchange and knowledge, to which he sent specimen plants. He also prepared a list of Cape trees and shrubs, Silva Capensis (1862), for a display of indigenous plants at the Paris Universal Exhibition of 1862 (though the exhibit was not included). ${ }^{78}$ A friend of Baron Carl von Ludwig, a pharmacist and businessman who assembled a private garden at his home in Kloof Street, Pappe was able to stock the revived Botanic Garden with trees and shrubs from the deceased Ludwig's estate.

Pappe's scientific importance rests on his awareness of the extraordinary variety and uniqueness of the Cape's botanical kingdom, his appreciation of the need to conserve these resources, and his understanding of environmental change - in particular the dangers of degradation through the practice of veld burning. Unlike pioneer botanists who travelled through the Cape, collected specimens, and then returned home to Europe in order to publish their scientific findings, Pappe chose to build his reputation at the Cape. He successfully maintained local as well as international connections and helped, both at Ludwig's private garden and, subsequently, in the public sphere, to accord status and standing to Cape Town's new scientific centres of calculation. Like the museum and library, these gave scope to local collectors and enthusiasts, providing a repository for donations and a

76 'Hortulanus', 'A Cape Botanical Garden, as It Should Be', Cape Monthly Magazine, 2, 9 (1857); Report of the Select Committee on the Botanical Garden, House of Assembly, 1856, iii-iv.

77 C. W. L. Pappe, Florae Capensis Medicae Prodromus; or an Enumeration of South African Plants Used as Remedies by the Colonists of the Cape of Good Hope, 2nd edition (Cape Town: W. Brittain, 1857).

${ }^{78}$ Beinart, Rise of Conservation, 74-5. 
focus for talks, research and writing. Locally published journals like the Cape Monthly Magazine and its Grahamstown rival, the Eastern Province Monthly Magazine, became vital outlets for the exchange of scientific and literary ideas.

The field sciences were particularly well suited to the accumulation of local expertise by amateur scientists. Botany provides a good example because it was an enthusiasm that could be pursued both for aesthetic and scientific reasons. Notably it was a science that included women as well as men. In genteel Victorian society, flower arranging had traditionally been part of the female domain. The fashion for botanical painting drew in women artists and botanical 'picnics' provided occasions for family excursions. Following Anna Maria Truter (Barrow's wife) in the late eighteenth century, Margaret Herschel was an expert painter of Cape flora, as was Arabella Roupell, whose Specimens of the Flora of South Africa, by a Lady (London, 1849) was published to satisfy the exotic tastes of an exclusive group of English subscribers that included Queen Victoria. Katherine Saunders and Marianne North, both socially wellconnected English botanical collectors and travellers, spent extended periods in South Africa in the second half of the nineteenth century.

With the establishment in 1854 of Representative Government in the Colony, parliament provided another vehicle for detailed inquiries and reports that fed into these scientific streams. For example, Andrew Wylie, first government geologist (1855-9), wrote in detail about the mineral resources of the Colony. Pappe and his successor, John Croumbie Brown, published annual reports on botanical matters. In 1860, a parliamentary select committee reported on Xanthium spinosum, spiny burrweed, a coloniser from South America that stuck in the wool of sheep, which was by then the Colony's most valuable export. It was the first plant to be declared a noxious weed. Committees and commissions sat to collect evidence on irrigation, drought and forestry. They drew on the knowledge of members of parliament and of farmers, as well as on early scientific experts where available.

\section{Geology and Palaeontology}

Geology, like botany, was a foundational science in South Africa, which drew freely on new approaches to the study of earth history in Britain especially. Foremost among the self-taught geologists at the Cape was Andrew Geddes Bain, who arrived from Scotland in 1816, 
settled in Graaff-Reinet, and embarked on an itinerant career as a saddler, hunter, ivory trader, explorer and road-builder. In the 1820s he travelled north to Tswana territories and east to Mpondoland, where he briefly met King Faku and encountered the trader Henry Fynn. ${ }^{79}$ Bain kept journals of his journeys and wrote frequently for newspapers. He absorbed some of the eastern Cape prejudices, expressed in his dramatic comedy Kaatje Kekkelbek; or Life among the Hottentots (1838), which satirised the work of the emancipationist missionaries. It is often credited as an early example of creolised Afrikaans literature.

In Britain, William Smith made observations for his first geological map, and found fossils, while surveying and engineering canals. ${ }^{80}$ In South Africa, Bain's introduction to geology came in the process of building roads and engineering extraordinary mountain passes. In 1837, while constructing the Queen's Road from Grahamstown to Fort Brown, Bain chanced on Charles Lyell's Principles of Geology (1830-3), whose uniformitarian account argued that the earth's existence went back much longer than the conventional 6,000 years since Creation. Lyell's ideas had an immediate influence on Bain. He pronounced himself 'smitten' and advanced his knowledge of the subject with further reading, including Gideon Mantell's Wonders of Geology (1838) which popularised the study of geology and fossil-hunting for an enthusiastic Victorian audience.

Together with William Borcherds (the civil commissioner of Fort Beaufort) and Atherstone, Bain hunted for fossils in the Karoo hinterland. His search was rewarded in 1838, when he chiselled a strange turtle-like skull with a beak and two canine tusks that corresponded to no known animal. He called it 'Bidental' and in 1844 sent it to the Geological Society of London. In 1845, the year in which he described his findings in the Transactions of the Geological Society of London, Bain's confidence was boosted by a grant from the Society. In England, the Bidental remains aroused the intense interest of T. H. Huxley and Richard Owen, who used the name Dicynodont (two dog teeth) to characterise the extraordinary mammal-like reptile (now known as a therapsid). In tribute, he named Bain's specimen Oudenodon bainii in 1860. Bain was also associated with the first fossil mammal to be

${ }^{79}$ M. H. Lister (ed.), Journals of Andrew Geddes Bain (Cape Town: Van Riebeeck Society, 1949).

80 S. Winchester, The Map That Changed the World: A Tale of Rocks, Ruin and Redemption (London: Penguin, 2002). 
collected in South Africa, called Pelorovis bainii. This buffalo-like creature was found around 1839 on the Modder River and sent to the South African Museum. Bain viewed the fossil remains, measuring and describing them in a letter to Andrew Smith. The information then went on to Charles Darwin, who reported it to the Geological Society of London. ${ }^{81}$ These networks and associations created a critical mass of interest in Cape palaeontology.

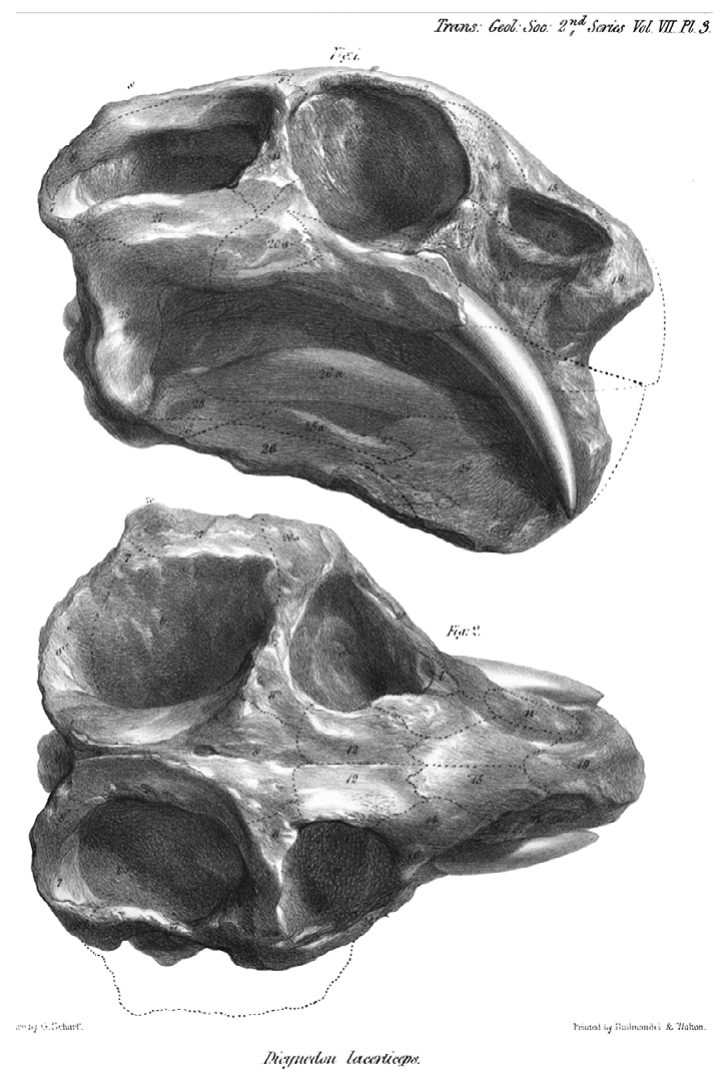

Figure 2.2 Side and upper views of the fossil skull of Dicynodon lacerticeps, a mammal-like reptile from South Africa, discovered by Andrew Geddes Bain and sent to Richard Owen. Drawing by George Scharf.

Credit: The Geological Society of London

81 Summers, History of the South African Museum, 31. 
Using his prestige and authority to control the collection and description of these dicynodont fossils from the Karoo, Owen also took receipt of a further collection sent to the British Museum by Governor Grey and reciprocated by naming one of the species Oudendon greyii. ${ }^{82}$ Other South African collectors were not so well honoured. For example, Alfred 'Gogga' Brown sent a large collection of fossils from the Stormberg region to T. H. Huxley, who used the material without due acknowledgement or recompense. ${ }^{83}$ Atherstone expressed disappointment in 1871 that the fossil bones unearthed by himself and Andrew Bain 'lie still in the vaults of the British Museum, unknown, unnamed, unexamined'. ${ }^{84}$ Collectors on the far-flung periphery of the British Empire could just as easily be acknowledged - or taken for granted and ignored.

Bain was also responsible for producing the first comprehensive stratigraphic survey of South Africa, published in 1856, and acclaimed by the Geological Society of London. ${ }^{85}$ He posited the remarkable idea that the interior bowl of the Cape, centred on the Karoo beds, had once been a vast freshwater lake, possibly double the size of all the Canadian lakes combined. Together with Atherstone and the Port Elizabeth doctor and palaeontologist, Richard Rubidge, Bain contributed articles on geology to the Eastern Province Monthly Magazine in a conspicuous act of identification with this region of the Cape Colony.

Geology was one of the first sciences in receipt of state support: the Cape Colony retained Andrew Wyley from 1854 to 1859 to conduct survey work on mineral deposits. P. C. Sutherland, who was medically trained and in 1850 sailed to Baffin Bay on an expedition to find survivors from Franklin's Arctic expedition, served Natal as its government geologist from 1854 and subsequently as surveyor-general. George Stow worked for a period as a geologist on behalf of the Orange Free State and Griqualand West administrations. The

82 Professor Owen, 'On Some Reptilian Fossils from South Africa', Quarterly Journal of the Geological Society, 16 (1860), 49-63.

83 M. R. Drennan, Gogga Brown: The Life-Story of Alfred Brown, South African Hermit-Naturalist (Cape Town: Maskew Miller, 1938).

${ }^{84}$ W. G. Atherstone, 'From Graham's Town to the Gouph', Cape Monthly Magazine, April (1871), 307.

85 A. G. Bain, 'On the Geology of South Africa', Transactions of the Geological Society of London, series 2, 7 (1856), 175-92; A. G. Bain, 'Geology of South Africa', Eastern Province Monthly Magazine, 1 (Sept. 1856) and 1 (June and July 1857). 
English-born Stow arrived in 1843 in the eastern Cape where he worked as a teacher, military officer, trader and farmer. In the midst of the frontier war of 1850-3, Stow discovered reptilian fossils that were described in the Quarterly Journal of the Geological Society (1858). He was elected a fellow of the Geological Society of London in 1872. Stow's 'Geological Notes upon Griqualand West', published in the Quarterly Journal (1874), were based on work commissioned by the governor of the Cape Henry Barkly. Stow is today best known for his descriptions of rock art, another of his enthusiasms.

Geology received a significant boost as a result of the discovery of diamonds and coal, and it was through commissions to search for such riches that self-taught geologists like Atherstone and Stow developed parallel interests in ethnology and palaeontology. The mineral revolution, diamonds and gold in particular, transformed South Africa's cultural, political and intellectual environment almost as profoundly as it affected its political economy.

\section{Imagining the Deep Past: The Beginnings of Archaeology}

Gender and racial boundaries restricted scientific training to white men in the first half of the nineteenth century. However, a limited number of white women in Britain were able to navigate patriarchal norms and establish themselves as scientists, often utilising family networks. Although medical training was barred to women, Mary Somerville forged a specialism in mathematics, largely self-taught, and was supported by her second husband, William Somerville, who had briefly worked at the Cape. Likewise, Caroline Herschel was able to become an innovative astronomer by working with her brother, William, father of John Herschel, who worked in close association with his wife, Margaret, a talented artist.

Mary Elizabeth Barber (1818-98), a member of the large Bowker family of eastern Cape British settlers, was one of the few who was able to pursue scientific interests systematically and to write about botany, entomology, zoology, ornithology, lepidoptery and archaeology. Initially she focused on botany, drawing and collecting plants and became an authority on the beautiful but foul-smelling Stapelia succulents. William Harvey, who worked at the Cape in the 1830s as treasurer-general, used the opportunity for botanical collection and published a short book in 1838, inviting collectors to correspond with 
him. This led to a sustained connection with Barber, who sent dried specimens, notes and illustrations. After his appointment to Trinity College Dublin in 1844, Harvey started a comprehensive herbarium and the publication of Flora Capensis (from 1859), drawing extensively on Barber's specimens. She also corresponded with Darwin and William Hooker at Kew. William Atherstone, a relative, interceded with the British scientists to ensure that Barber's achievements as a botanist and illustrator were recognised in spite of her gender. ${ }^{86}$ That was not fully achieved, but she published in the prestigious journal of the Linnean Society in 1870 - the first South African to do so.

Barber was an inventive thinker and early adopter of Darwin's theory of natural selection. At a time when studies of animals were moving from the classificatory and anatomical to consider animal behaviour, she drew on Darwin to develop new insights into mating relations in birds. Hammel argues that Barber saw female birds as equally active in sexual selection and thus viewed mating as a 'space of gender equality'. ${ }^{87}$ She implicitly questioned the way in which male ornithologists theorised bird behaviour by applying Victorian gender stereotypes. Barber also contributed to a range of other debates, from the environmental degradation caused by millions of sheep in the Cape to the mesmerising effects of snakes on their victims. ${ }^{88}$

On the question of race, however, Barber was anything but enlightened. Like many eastern Cape whites, she was firmly of the view that black people were intellectually inferior to white. ${ }^{89}$ Although Barber learned about the medicinal and toxic properties of plants through direct or indirect association with Khoesan, Xhosa and Afrikaner medical practitioners and naturalists, she did little to credit their contribution to her own botanical knowledge. ${ }^{90}$

Mary Barber's brothers, known primarily for their military roles in wars against the Xhosa in the eastern Cape, were also associated with scientific advance. James Henry Bowker was a noted lepidopterist and plant collector. He and his sister fostered a close working relationship

${ }^{86}$ Hammel, 'Shaping Science and Society', 109-10.

${ }^{87}$ T. Hammel, 'Thinking with Birds: Mary Elizabeth Barber's Advocacy for Gender Equality in Ornithology', Kronos, 41, 1 (2015), 85-111.

88 A. Cohen, 'Mary Elizabeth Barber, the Bowkers, and South African Prehistory', South African Archaeological Bulletin, 54, 170 (1999), 120-7; Beinart, Rise of Conservation, 117.

${ }^{89}$ Beinart, 'Men, Science’. $\quad{ }^{90}$ Hammel, 'Shaping Science and Society', 62-3. 
with Ronald Trimen of the South African Museum, to which he donated a collection of butterflies in $1860 .{ }^{91}$ Another collection of Bowker's butterflies and moths was presented to the Albany Museum in Grahamstown. Thomas Holden Bowker is credited with being the first to accumulate a systematic collection of stone artefacts in South Africa.

The big questions being raised by geology and fossil collection led to a recognition of stone tools as the product of ancient societies. In 1857-8 Thomas Bowker identified stone points as arrowheads crafted by humans, after being shown Danish equivalents by Edgar Layard. The similarities caused Bowker to believe that they must have been produced by white people. Mary Barber disagreed because, in line with her evolutionist views, she could not countenance the possibility that white inhabitants had somehow vanished from history. Samples from Bowker's collection were donated in 1866 to the Royal Artillery Museum in London, where they remained for a century until they were returned to South Africa for display in the Albany Museum. ${ }^{92}$ Stone implements found by James Henry Bowker at Pniel near Kimberley, and in Lesotho, were sent to the British and the South African Museums.

In the 1860s the Cape educationist, Langham Dale, a frequent contributor to the Cape Monthly Magazine (he wrote as 'Delta'), found and recognised stone tools on the Cape Flats near his home at Mowbray. In an article published in 1870, Dale introduced his readers to the subject of archaeology, referring to it as a 'new science interposing itself between Geology and History'. ${ }^{93}$ Dale was aware of related finds in Europe, Japan and Australia, and he followed with avid interest debates about the antiquity of palaeoliths arising from Boucher de Perthes's discoveries in the Somme Valley. Dale was also acquainted with the recent work of John Lubbock, originator of the terms 'palaeolithic' and 'neolithic', who was a strong supporter of

91 Hammel, 'Shaping Science and Society', 102-3.

92 H. J. and J. Deacon, Human Beginnings in South Africa: Uncovering the Secrets of the Stone Age (Cape Town: New Africa Books, 1999), 2-3; S2A3

Biographical Data Base: T. H. Bowker, www.s2a3.org.za/bio. Barber later changed her mind and came to believe that perforated stones may have been made by a lost tribe of Israel.

93 Delta, 'Stone Implements in South Africa', Cape Monthly Magazine (New Series, October 1870), 236. 
Darwin's still controversial theory of evolution. No supporter of Darwin, Langham Dale's views carried weight at the Cape on account of his key position in the Cape educational establishment. He served as superintendent-general of education at the Cape from 1859 to 1892 and also played a major role in the creation in 1873 of the University of the Cape of Good Hope, which he went on to lead as vice-chancellor and chancellor.

In his essay on archaeology, Dale was clear that the 'rude' specimens of pottery, arrowheads and scrapers he inspected were fashioned by 'native races'. Yet, in his opinion there was as yet nothing to suggest that they were 'prehistoric'. ${ }^{94}$ Stimulated by Dale's intervention, Alfred Brown, fossil collector in Aliwal North, drew attention to ancient mounds, stone implements, and 'innumerable paintings representing the history and habits' of cave dwellers, probably Bushmen, in the vicinity of the Stormberg. Some of the bones associated with these finds were 'in a sub-fossil condition', but Brown could not be sure that the stone tools were of the same age as the 'mammalian remains' found with them. ${ }^{95}$ In 1871 Atherstone, now deeply engaged in geology and palaeontology, reported on caves in Mossel Bay where significant accumulations of shells were to be found. The same year, Henry Piers of the South African Museum found shell mounds in caves far above sea level at sites around the False Bay side of the Cape Peninsula. In the columns of the Cape Monthly there was vigorous debate as to what these discoveries meant. Might they be the result of geological upheaval rather than human habitation? Were birds or inanimate forces such as the action of the sea responsible for such deposits?

Piers, a frequent contributor on the geology of the Cape Peninsula, thought it 'inconceivable' that shell middens might be the work of ancient human hands, notwithstanding evidence of entombed human skeletons in caves to the north. ${ }^{96} \mathrm{~A}$ much bolder explanation was offered by Dr Peter Comrie, naval surgeon and naturalist, who visited the Cape en route to New Zealand on the naval ship Basilisk. Comrie, after examining arrowheads, pottery, perforated stones and human remains at Cape Point, dismissed various theories including the notion

94 Delta, 'Stone Implements in South Africa', 237.

95 Note from 'AB' in Cape Monthly Magazine, December (1870), 366-7, appended to an article by Delta, 'Stone Implements in South Africa', 365-6.

${ }^{96} \mathrm{H}$. W. Piers, 'On the Geology of the Cape Peninsula', Cape Monthly Magazine, September (1871), 172. 
that shells found in elevated caves might have been brought there by birds. He was also impressed by samples of pottery, reticulated on the inside, which were shown to him by P. D. Martin of Simonstown. In an article entitled 'The Stone-Age at the Cape of Good Hope', Comrie declared in 1874 that these finds were evidence of prehistoric peoples, indicating that 'our present civilization is the result of simple and rude beginnings. In the language of the first writer on this subject, De Perthes, "Let us not, then, disdain these few essays of our forefathers." "97

Meanwhile, research undertaken by the linguist Wilhelm Bleek was revealing the 'astonishing' traditional literature - or 'folklore' - that might have been 'first told in those so-called pre-historic times when the art of smelting any metal was still unknown, and when stone implements were the only ones in use'. It was as yet too early to speculate on their origins, but he thought it was clear that tales with similar structures reappeared in the 'remotest parts of the earth' and 'there is clear evidence that a literature of fables existed among the Hottentots before the advent of Europeans'. ${ }^{98}$ In 1874, Bleek commented enthusiastically on newly described and reproduced Bushman paintings from the Maloti Mountains, sent to the Cape Monthly Magazine by Joseph Millard Orpen, a leading colonial official and expert on Basutoland. In Bleek's view, the rock paintings cast 'a good deal of new light upon the subject of Bushman mythology, and upon the vastness of the legendary lore of this highly curious people'. ${ }^{99}$ Bleek's pronouncement was amply borne out, for Orpen's article relating his encounters with a Bushman guide named Qing, remains one of the foundations of contemporary understandings of Bushman mythology and rock art. ${ }^{100}$

In the view of William Bisset Berry, a physician based in Queenstown who later became a prominent politician and speaker of the House of Assembly, evolutionary theory was soundly based. Berry

97 Dr Comrie, 'The Stone-Age at the Cape of Good Hope', Cape Monthly Magazine, November (1874), 290.

98 W. H. I. Bleek, 'African Folk Lore', Cape Monthly Magazine, September (1870), 168-9.

99 J. M. Orpen, 'A Glimpse into the Mythology of the Maluti Bushmen', Cape Monthly Magazine, July (1874), 1-10 with 'Remarks by Dr. Bleek', 10-13.

100 R. King, “"A Loyal Liking for Fair Play”: Joseph Millerd Orpen and Knowledge Production in the Cape Colony', South African Historical Journal, 67, 4 (2015), 410-32. 
took issue publicly with Langham Dale in the columns of the Cape Monthly, but his painstaking rebuttal of Dale's position was a minority one. Just a few years before, in 1867, Berry's support of evolution was sufficiently controversial to make him temporarily leave Queenstown to take up a medical practice in the small town of Burgersdorp. Langham Dale's circumlocutory prevarications on the matter of evolution, as evidenced in his 1874 public address at the South African Public Library, were evidently more in keeping with the mood of the anglophone intelligentsia. ${ }^{101}$

Darwinian ideas were nevertheless gaining currency, and debates in the Cape Monthly were conducted in a respectful spirit of positive, if prudent, inquiry. It was while on a government-sponsored expedition in 1870 to verify reports of gold found in a remote region of the Karoo between the Swartberg and Nieuweberg mountains that Atherstone declared the real 'nuggets' were not bullion but extraordinary rock formations and evidence of Silurian fossils. He wrote a facetious travelogue in which he joked about the lazy, ignorant farmers he encountered and wondered, in a gesture to degenerationist theories, what the Darwinians would say 'of this undoubted development of Boer into Hottentot by the mere solarisation of a dozen summers' ${ }^{102}$ This parodic treatment did not require Atherstone to declare his own view on the scientific veracity of natural selection, but it did indicate that such ideas were in the air and that there was a public eager to find out more.

Such responses - anxiety, willing acceptance, or jokes about primitive man and hints of polygenesis in the case of Atherstone - are indicative of the different ways in which human evolution was considered by Cape-based intellectuals in the 1870 s, less than two decades since the first mention of shell middens was raised by way of a 'query' in the Cape Monthly Magazine by 'Barnacle'. Darwin's Descent of Man (1871) rather than the Origin of Species (1859) provided a further challenge. Langham Dale's intellectual and social conservatism led him to address, ponderously, the question of human origins and

101 D. N. Livingstone, Dealing with Darwin: Place, Politics, and Rhetoric in Religious Engagements with Evolution (Baltimore: Johns Hopkins, 2014), 16-18; Dubow, A Commonwealth of Knowledge, 96-9.

102 W. G. Atherstone, 'From Graham's Town to the Gouph', chapter III, Cape Monthly Magazine, July (1871), 50. 
evolution as a compelling but unproven hypothesis. As well as scriptural objections to the theory of evolution, which were shared by investigators in Europe, Darwinian ideas raised particular problems in the context of the colonial Cape where conceptions of deep time and history brought to the fore alluring but troubling questions about sequences of human habitation and the increasingly vexing issue of racial origins and hierarchies. ${ }^{103}$ Quite aside from theological issues, the implications of revealing that the country might have been inhabited for millennia by people who were not from Europe were profoundly disturbing. Yet by the 1870s, Comrie, Bleek, Orpen, Stow, and others were beginning to assemble a deepening understanding and imagination of just such societies, with stone tools, middens and rock art building a picture made of an ever-denser array of pixels.

\section{New Connections}

As is clear from the first two chapters, Cape society was not isolated from Europe; ideas and networks were carried by sea in both directions over $10,000 \mathrm{~km}$. Shipping routes were the sinews of the maritime empires and until 1869, when the Suez Canal opened, every vessel going from Europe to the Indian Ocean, Asia or Australasia passed, and generally stopped at, a South African port. A mail steamship became a regular feature of the passage to England from the early 1850s; in 1857 the Union line won the mail contract and also started services between Cape Town and Durban. A sailing ship took around three months to reach the Cape in 1800; Thomas Pringle, 1820 settler, was at sea for about seventy-four days. By 1876, when the Castle line joined the Union as a mail carrier, steamships cut this to thirty days. Within the Colony a twice-weekly postal service, transported by horse, linked the main centres. The arrival of ships in Table Bay was closely watched and anticipated.

The first railway out of Cape Town reached Wellington in 1863, and in 1879 lines arrived at Graaff-Reinet and Grahamstown. Internal telegraphic communication was slow to take off. It was possible to

103 Unsigned review of Darwin's 'The Descent of Man', Cape Monthly Magazine, June (1871), 321-30, which treats the 'highly speculative' theory of evolution with noncommittal respect; also Langham Dale 'Anthropology: A Review of Modern Theories', Cape Monthly Magazine, May (1874), 350-61. 
send messages between Cape Town and Simonstown in 1860, and Grahamstown in 1863, but telegraphs remained a novelty. The utility of the medium was proved in 1878 when the colonial governments were warned by telegraph of the imminent war against the Zulu. ${ }^{104}$ Over the course of this great conflict, military requirements and public hunger for information expressed itself in a need for more rapid links with Britain. This was partly achieved with the extension of an unreliable telegraph link to London, via Aden, at the end of 1879. A direct link with London was only securely established by the time of the South African War.

The increase in transoceanic maritime traffic required a major improvement in the capacity of the Cape Town harbour; work on a new breakwater and dock began in 1860. In the same year the acting colonial secretary, Richard Southey, an eastern Cape farmer and government administrator with a range of scientific interests, became inaugural chair of the Cape government's Meteorological Commission, effectively the first weather service in southern Africa and one of the oldest in the world. ${ }^{105}$ From a small, isolated rural colony at the turn of the nineteenth century, with few institutions other than those directly linked to the government and the maintenance of order, the Cape was now a distinctly more connected society. The first parliament in 1854 and the grant of Responsible Government in 1872, with an elected Prime Minister, helped to expand the range of scientific initiatives sponsored by the government.

The scientific and literary societies that took root from the late $1820 \mathrm{~s}$ did much to encourage intellectual curiosity and activity. By expanding the public sphere, institutions became important loci of colonial knowledge and self-awareness. Together with the battle to publish without censorship and to express civil and political autonomy, associations and societies - including journals, libraries, museums and botanical gardens - gave expression to an assertive sense of colonial pride and respectability. Many of the politicians who led the movement for selfgovernment - John Fairbairn, William Porter, Saul Solomon among

104 A. F. Hattersley, An Illustrated Social History of South Africa (Cape Town: A. A. Balkema, 1969), 208-10.

105 P. R. de Kock and H. D. Moraal (eds.), 'Physics in South Africa', unpublished manuscript (2011), 417. 
them - were intimately connected with the development of the particular brand of Cape liberalism that expressed itself through intellectual, scientific, and cultural as well as economic pursuits.

While the western Cape remained the fulcrum of institutional development and scientific knowledge, rival developments were evident in the eastern Cape, supported by a rapidly growing agrarian economy, and also in the neighbouring colony of Natal. Over this period of seventy years, independent African kingdoms such as the Zulu innovated in spheres of indigenous knowledge and incorporated colonial technology in attempts to centralise political power. While they were increasingly drawn into the colonial web, they remained significant alternative nodes of authority and power.

By this time, substantial scientific activity was evident in fields such as astronomy, botany, geology and medicine. Awareness of South Africa's deep history and rich ethnography was stimulated by growing interest in archaeology, linguistics and rock art. Theories of evolution helped to frame questions of deep time, patterns of human habitation, and progress. As well as the rapid assimilation of books and journals arriving from overseas, newspapers and journals like the Cape Monthly Magazine and the Eastern Province Monthly Magazine served as vital conduits for discussion and debate. Prior to the establishment of universities, these were the networks that built on an older, traveller-based scientific curiosity, coalescing in a new, locally based, largely anglophone scientific imagination. The institutions of this time, such as the museums, libraries and gardens, survive to the present day as national assets.

As yet, scientific specialisation and professionalisation were limited: there was no teaching university in existence, nor any system of statefunded research. But a wide range of research was being generated by accomplished amateurs with close links to government institutions who regarded the Cape Colony as their permanent place of residence. The establishment of a parliamentary system began to give scope to detailed inquiries on matters of applied science through government commissions. Although no party system had yet been established in parliament, political differences corresponding to humanitarians and anti-humanitarians, Dutch- and English-speakers, colonial nationalists and imperialists were taking clear form. Aside from interest in phrenology, there were as yet few sustained intimations of the brand of social Darwinism that came to express itself, from the 1870s, in 
efforts to classify and rank different races in terms of racial superiority and inferiority, and to impute corresponding political rights. Such ideas were about to coagulate as processes of colonial conquest and industrialisation gathered momentum. In such discussions and debates, intellectual ideas played no small part. 